\section{The impact of migration on body weight: a review}

\author{
O impacto da migração no peso corporal: \\ uma revisão
}

\section{El impacto de la migración sobre el peso corporal: una revisión}

\begin{abstract}
Immigrants may be more vulnerable to obesity as a result of the immigration process. The aim of this article is to summarize current knowledge about the impact of immigration on body mass index (BMI). A systematic review was performed in accordance with PRISMA guidelines through a database search of scientific articles (last updated in August 2014). Thirty-nine articles were included and assessed. Results varied according to ethnic background, country of origin and host country. A consistent positive association between BMI and time since immigration was found among Hispanic, European and African immigrants. Less than half of the studies observed a positive association among Asian immigrants. The quality of the majority of the studies assessed was poor, reflecting a need to improve methodology and concept definition. Immigration appears to have a deteriorative effect on BMI. Underlying causes may include changes in nutrition and physical activity, psychological and social factors, and genetic susceptibility and these aspects should be included as moderator variables in future studies.
\end{abstract}

Emigration and Immigration; Acculturation; Obesity
Beatriz Goulão ${ }^{1}$

Osvaldo Santos 1

Isabel do Carmo ${ }^{1}$

\section{Resumo}

A obesidade pode ser uma das características mais alteráveis no processo de migração. Pretendeu-se resumir a informação sobre o impacto da migração no índice de massa corporal (IMC). Realizou-se uma revisão sistemática da literatura de acordo com as diretrizes PRISMA, por meio de pesquisa eletrônica (última atualização em agosto de 2014). Foram incluídos e avaliados qualitativamente 39 artigos. A associação entre migração e evolução de IMC varia de acordo com o grupo étnico e países de origem/ acolhimento. Imigrantes hispânicos, europeus e africanos apresentam relação consistente e positiva entre IMC e tempo de migração. Os imigrantes asiáticos apresentam associação positiva em menos da metade dos estudos. No geral, a qualidade dos estudos é fraca e há necessidade de melhorar conceitos e métodos. Parece existir um efeito deteriorativo da migração no IMC. Alterações nutricionais, de atividade física, fatores psicossociais e suscetibilidade genética podem ser motivos subjacentes a incluir como variáveis moderadoras em estudos futuros.

Migração Internacional; Aculturação;

Obesidade 


\section{Introduction}

There is a growing interest in the association between immigration and food consumption. Food and beverages play a key role in maintaining social and cultural connections among immigrants. Over time, food consumption among immigrants tends to change due to acculturation and lack of availability of typical food products from their home country $1,2,3$.

An association has been observed between dietary acculturation and immigrant integration into the host country and a deterioration of diet among immigrants 4 . Immigration often leads to changes in the quality of food consumed and cooking methods. Immigrants are susceptible to a rapid change in emphasis towards convenience foods, such as snacks and sweets, while the consumption of staple foods like rice and corn remains unchanged over longer periods of time 5. Studies show that the factors that affect eating habits among immigrants include food availability, income, beliefs relating to food, religion and "food laws", and the generation and age of immigrants 5 .

Dietary acculturation does not always have negative results. In a study of Moroccan immigrants carried out in Spain, food choices were more varied and nutritionally-dense among of the most acculturated immigrants 6 . The authors also concluded that recent immigrants with poor fluency in Spanish may have difficulties in accessing a large variety of foods.

Other studies suggest that the initial health status of immigrants is better than that of the population of the host country. This phenomenon is known as the "healthy immigrant effect" 7 . However, this effect often disappears as length of residence increases 7,8 . On the other hand, comparative studies show that after immigration the risk of diseases associated with obesity, such as cardiovascular disease, diabetes, and cancer, may change over time ${ }^{7}$. Susceptibility to obesity [defined as body mass index $(\mathrm{BMI}) \geq 30 \mathrm{~kg} / \mathrm{m}^{2}$ ] 9 increases with immigration and length of residence in the host country. Evidence from studies carried out in the United States suggests that recent immigrants generally have a lower BMI than the American population. However, BMI tends to increase as the length of residence in the host country increases, progressively converging towards the levels of the American population 7 . The same phenomenon has been observed by studies in Canada, Australia and Europe ${ }^{8}$.

Studies of this phenomenon in other countries are scarce. Four of the five systematic reviews of this issue concentrate exclusively on obesity among the US immigrant population.
Misra \& Ganda 10 analyzed this issue from a global perspective. However, the study was published in 2007 and lacks a qualitative assessment of the papers included. The present article is the result of an updated systematic review of studies to analyze the association between length of time since immigration and body weight among first generation immigrants.

The review was worldwide, including countries for which data was available, and focused on two approaches to research which address the links between immigration, acculturation and weight gain among first generation immigrants. The first uses length of residence in the host country as a proxy measure of acculturation. Although a very common approach, the validity of this assumption has yet to be fully demonstrated in the literature 9 . The second area of research compares immigrants living in the host country with their counterparts living in their home country.

\section{Methods}

A systematic review was conducted in accordance with PRISMA guidelines 11 through a search of published studies contained in the PubMed, JSTOR and EBSCO databases, with no publication date restrictions. The search was conducted initially on July 27th 2011 and updated on August 8 th 2014 . The following combined keywords were used as alternatives in order to obtain as many studies as possible: "immigrant"; "migrant", "foreign-born”; "country of birth”, "country of origin”; "region of birth", "region of origin”; "BMI”, "body mass index"; "overweight”, "obesity”; "body weight" and "duration", "length of stay"; "time"; "acculturation".

The titles and abstracts of the identified papers were independently screened by the first two authors who arrived at a consensus on eligibility and content. The full texts of potentially relevant papers were assessed for eligibility based on the following criteria: (i) papers must describe original work; (ii) studies include adults born in foreign countries (first generation immigrants) and respective specific data about the variables of interest; (iii) measure of overweight or BMI (or change in these variables) is a key/endpoint variable - whether self-reported or not; (iv) studies include length of residence in the host country or amount of time spent in the host country as a key/independent variable; (v) studies include data that allows comparison of immigrants groups and nonimmigrant counterparts from the immigrant's country of origin; (vi) full texts are in English, Spanish or Portuguese. Studies that 
focused only on children or teenagers, regardless of whether they were first generation immigrants, were excluded. Generally this group is not entirely independent in their food and leisure physical activity choices, and choice of where to live, and therefore the factors that influence the variables in this group are different to those influencing adult immigrants.

Data was extracted into a standardized matrix that included the title of the article, name of the scientific journal and publication, host country, population and comparison groups (if applicable), main outcome (BMI, overweight/obesity, change in BMI), statistical analysis, covariates used, and main results.

The first two authors independently appraised the quality of the evidence produced by studies focussing on the impact of immigration on obesity based on the following criteria: (a) recruitment strategy; (b) sample size; (c) whether participation rate was reported; (d) participation rate; (e) well defined eligibility criteria; and (f) overall adequacy of methods. The results for each criteria were used to generate a final score, ranging from 0 (low relevance) to 7 (high relevance).

\section{Results}

The study selection process is shown in Figure 1. A total of 39 articles from an initial list of 365 citations were considered eligible for this review. These articles were published between 2000 and 2014 and based on studies in the following countries: the United States (25), Canada (4), the Netherlands (1), Spain (1), Italy (1), Israel (1), France (1), Norway (2), Luxembourg (1), Sweden (1) and the United Kingdom (1).

Sample sizes varied between 5312 and 478,276 individuals ${ }^{13}$. Table 1 shows that a number of papers included in this review did not include relevant details about methodology, particularly sampling and recruitment techniques and participation rates, thus compromising the quality of the evidence.

\section{Length of residence in the host country as a determinant of increases in BMI}

Significant disparities were observed between immigrant sub-groups with regard to the association between length of time since immigration and BMI 13. Results are therefore presented by immigrant group (Table 2) showing the results for specific countries of origin where available. Some studies therefore appear more than once. We show the most prevalent religion among immigrants and first language based on the region
Figure 1

PRISMA fluxogram

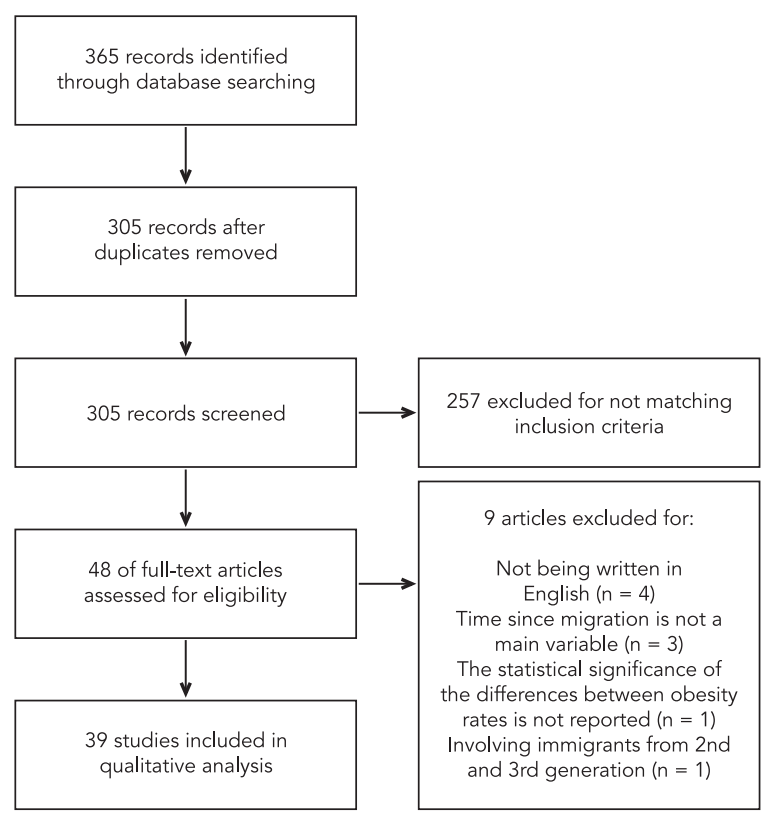

of birth to facilitate the grouping of immigrants and the interpretation of potential acculturation barriers. Four of the studies 12,14,15,16 used only female samples. All but one of the studies 17 sampled only adults. All but one of the studies 18 were cross-sectional. One study consisted of a repeated cross-sectional survey to evaluate changes in the prevalence of obesity among immigrants and US-born individuals 19. BMI was self-reported in the majority of the studies. Ten of the studies measured weight and height $14,16,18,20,21,22,23,24$, while one study measured only height and weight was self-reported 25 . In another study, weight and height were measured but change in BMI (outcome variable) was calculated based on self-reported past weight and height 26 . Only one study reported to have imputed missing data 27 . The variable length of residence in the host country was always defined using an interval scale, generally divided into recent $(<5$ years) and long-term (> 15 years). Eleven 13,17,20, 28,29,30,31,32,33,34,35 studies included all immigrant groups resident in the host country. Five studies $17,28,32,36,37$ showed the increase in length of residence in the host country but did not stratify the results by immigrant group. Another study 28 presented results by region of origin, concluding 
Table 1

Quality assessment of the studies reviewed.

\begin{tabular}{|c|c|c|c|c|c|c|c|}
\hline Authors & Host country & $\begin{array}{l}\text { Recruitment } \\
\text { strategy * }\end{array}$ & $\begin{array}{l}\text { Sample } \\
\text { size ** }\end{array}$ & $\begin{array}{l}\text { Participation } \\
\text { rate } \\
\text { (reported } \\
\text { or not) }{ }^{\star \star \star}\end{array}$ & $\begin{array}{c}\text { Participation } \\
\text { rate > } \\
75 \% \star \star \star\end{array}$ & $\begin{array}{c}\text { Eligibility } \\
\text { criteria well } \\
\text { defined *** }\end{array}$ & $\begin{array}{c}\text { Overall } \\
\text { appreciation } \\
\text { of relevance } \\
\text { of the article \# }\end{array}$ \\
\hline Koya \& Egede 28 & United States & 2 & 2 & 1 & 0 & 1 & $\uparrow \uparrow \uparrow$ \\
\hline Park et al. 20 & United States & 0 & 2 & 0 & 0 & 1 & $\uparrow$ \\
\hline Gutiérrez-Fisac et al. 32 & Spain & 2 & 2 & 0 & 0 & 1 & $\uparrow \uparrow$ \\
\hline Iversen et al. 26 & Norway & 1 & 2 & 1 & 0 & 1 & $\uparrow \uparrow$ \\
\hline Regev-Tobias et al. 12 & Israel & 1 & 0 & 0 & 0 & 1 & $\uparrow$ \\
\hline Novotny et al. 80 & United States & 2 & 2 & 0 & 0 & 1 & $\uparrow \uparrow$ \\
\hline Lauderdale \& Rathouz 39 & United States & 2 & 2 & 1 & 1 & 1 & $\uparrow \uparrow \uparrow$ \\
\hline Dijkshoorn et al. 42 & Netherlands & 0 & 2 & 1 & 0 & 1 & $\uparrow \uparrow$ \\
\hline McDonald \& Kennedy 30 & Canada & 2 & 2 & 0 & 0 & 1 & $\uparrow \uparrow$ \\
\hline Goel et al. 34 & United States & 2 & 2 & 1 & 0 & 1 & $\uparrow \uparrow \uparrow$ \\
\hline Roshania et al. 17 & United States & 2 & 2 & 0 & 0 & 1 & $\uparrow \uparrow$ \\
\hline Fu \& Vanlandingham 21 & United States & 2 & 1 & 1 & 0 & 1 & $\uparrow \uparrow$ \\
\hline Yeh et al. 63 & United States & 1 & 2 & 0 & 0 & 1 & $\uparrow \uparrow$ \\
\hline Barcenas et al. 38 & United States & 0 & 2 & 1 & 1 & 1 & $\uparrow \uparrow$ \\
\hline Sanchez-Vaznaugh et al. 81 & United States & 2 & 2 & 0 & 0 & 1 & $\uparrow \uparrow$ \\
\hline Lindström \& Sundquist 49 & Sweden & 2 & 2 & 1 & 0 & 1 & $\uparrow \uparrow \uparrow$ \\
\hline Albrecht et al. 18 & United States & 0 & 2 & 0 & 0 & 1 & $\uparrow$ \\
\hline Choi et al. 41 & United States & 1 & 0 & 1 & 0 & 1 & $\uparrow$ \\
\hline Tremblay et al. 33 & Canada & 0 & 2 & 1 & 1 & 1 & $\uparrow \uparrow$ \\
\hline Fuentes-Afflick \& Hessol 25 & United States & 0 & 0 & 1 & 1 & 1 & $\uparrow$ \\
\hline Wolin et al. 14 & United States & 0 & 1 & 0 & 0 & 1 & $\uparrow$ \\
\hline Toselli et al. 53 & Italy & 0 & 0 & 0 & 0 & 1 & $\uparrow$ \\
\hline Dey \& Lucas 82 & United States & 2 & 0 & 0 & 0 & 1 & $\uparrow$ \\
\hline Kaplan et al. 83 & United States & 2 & 2 & 1 & 0 & 1 & $\uparrow \uparrow \uparrow$ \\
\hline Oza-Frank \& Narayan 31 & United States & 2 & 2 & 0 & 0 & 1 & $\uparrow \uparrow$ \\
\hline Sanchez-Vaznaugh et al. 29 & United States & 2 & 2 & 0 & 0 & 1 & $\uparrow \uparrow$ \\
\hline Cairney \& Ostbye 36 & Canada & 2 & 2 & 0 & 0 & 1 & $\uparrow \uparrow$ \\
\hline Miller et al. 16 & United States & 0 & 0 & 0 & 0 & 1 & $\uparrow$ \\
\hline Chiu et al. 35 & Canada & 2 & 2 & 1 & 0 & 1 & $\uparrow \uparrow \uparrow$ \\
\hline Creighton et al. 27 & United States & 2 & 2 & 1 & 1 & 1 & $\uparrow \uparrow \uparrow$ \\
\hline Ullmann et al. 84 & United States & 2 & 1 & 0 & 0 & 1 & $\uparrow \uparrow$ \\
\hline Martin-Fernandez et al. 37 & France & 2 & 2 & 1 & 0 & 1 & $\uparrow \uparrow \uparrow$ \\
\hline Gele \& Mbalilaki 23 & Norway & 0 & 0 & 0 & 0 & 1 & $\uparrow$ \\
\hline Barhmal et al. 40 & United States & 2 & 2 & 1 & 1 & 1 & $\uparrow \uparrow \uparrow$ \\
\hline Riosmena et al. 85 & United States & 2 & 2 & 0 & 0 & 1 & $\uparrow \uparrow$ \\
\hline Parikh et al. 86 & United States & 1 & 1 & 1 & 0 & 1 & $\uparrow \uparrow$ \\
\hline Garduño-Diaz \& Khokhar 24 & United Kingdom & 0 & 0 & 0 & 0 & 1 & $\uparrow$ \\
\hline Park et al. 19 & United States & 2 & 2 & 0 & 0 & 1 & $\uparrow \uparrow$ \\
\hline Bhatnagar et al. 45 & United Kingdom & 0 & 1 & 1 & 1 & 1 & $\uparrow \uparrow$ \\
\hline Mahajan \& Bermingham 43 & Australia & 0 & 0 & 0 & 0 & 1 & $\uparrow$ \\
\hline Tennakoon et al. 46 & Norway & 2 & 2 & 1 & 0 & 1 & $\uparrow \uparrow \uparrow$ \\
\hline Kouris-Blazos et al. 50 & Australia & 2 & 0 & 1 & 1 & 1 & $\uparrow \uparrow$ \\
\hline Zahid et al. 44 & Norway & 2 & 2 & 1 & 0 & 1 & $\uparrow \uparrow \uparrow$ \\
\hline
\end{tabular}

* 0: non-randomized/convenience sampling; 1: randomized sampling (not national-based); 2: randomized sampling (national-based);

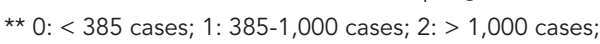

$\star \star \star 0$ : Criteria not met (e.g. participation rate not reported, participation rate $<75 \%$ and eligibility criteria not well defined); 1 : Criteria met (e.g. participation rate reported, participation rate $>75 \%$ and eligibility criteria well defined);

\# Computed as the sum of scores given to each of the five indicators (previous columns). This overall sum was subsequently recoded into in the following categories: $\uparrow$ Poor (less than 4 points); $\uparrow \uparrow$ Acceptable (4 to 5 points); $\uparrow \uparrow \uparrow$ Good (> 5 points). 


\section{Table 2}

Effect of length of residence on body mass index/overweight prevalence, by immigrant group.

\begin{tabular}{|c|c|c|c|c|c|c|c|}
\hline Immigrant group & $\begin{array}{l}\text { Sample } \\
\text { size }\end{array}$ & Host country & Country of origin & Official language/s & $\begin{array}{l}\text { (Most prevalent) } \\
\text { religion/s }\end{array}$ & Reference & $\begin{array}{c}\text { Association } \\
\text { with BMI/ } \\
\text { overweight } \\
\text { prevalence }\end{array}$ \\
\hline \multirow[t]{19}{*}{ Hispanics } & 7,503 & United States & Mexico & Spanish & Roman Catholicism & Barcenas et al. 38 & $\uparrow$ \\
\hline & 32374 & United States & * & * & * & Goel et al. 34 & $\uparrow$ \\
\hline & 174 & United States & Puerto Rico women & Spanish & Roman Catholicism & $\begin{array}{c}\text { Himmelgreen et } \\
\text { al. } 15\end{array}$ & $\uparrow$ \\
\hline & 2,420 & United States & $\begin{array}{c}\text { Mexico, Central and } \\
\text { South America or } \\
\text { Caribbean }\end{array}$ & $\begin{array}{l}\text { Spanish and } \\
\text { Portuguese }\end{array}$ & $\begin{array}{c}\text { Roman Catholicism } \\
\text { or Christianity }\end{array}$ & Kaplan et al. 83 & $\uparrow$ \\
\hline & 33,299 & United States & $\begin{array}{c}\text { Mexico, Central } \\
\text { and South America, } \\
\text { Caribbean Islands }\end{array}$ & $\begin{array}{l}\text { Spanish and } \\
\text { Portuguese }\end{array}$ & $\begin{array}{c}\text { Roman Catholicism } \\
\text { or Christianity }\end{array}$ & $\begin{array}{l}\text { Oza-Frank \& } \\
\text { Narayan } 31\end{array}$ & $\uparrow$ \\
\hline & 13,011 & United States & * & * & * & Park et al. 20 & $\uparrow$ \\
\hline & 37,350 & United States & $\begin{array}{c}\text { Mexico, Central and } \\
\text { South America, Puerto } \\
\text { Rico }\end{array}$ & $\begin{array}{l}\text { Spanish and } \\
\text { Portuguese }\end{array}$ & $\begin{array}{c}\text { Roman Catholicism } \\
\text { or Christianity }\end{array}$ & $\begin{array}{c}\text { Sanchez-Vaznaugh } \\
\text { et al. } 29\end{array}$ & $\uparrow$ \\
\hline & 154,649 & United States & * & $\begin{array}{l}\text { Spanish and } \\
\text { Portuguese }\end{array}$ & Roman Catholicism & Singh et al. 13 & $\uparrow$ \\
\hline & & & Cuba & Spanish & Roman Catholicism & & $\leftrightarrow$ \\
\hline & & & Mexico & Spanish & Roman Catholicism & & $\uparrow$ \\
\hline & & & Puerto Rico & Spanish & Roman Catholicism & & $\leftrightarrow$ \\
\hline & 388 & & Mexico & Spanish & Roman Catholicism & Wolin et al. 14 & $\uparrow$ \\
\hline & 126,796 & Canada & * & * & * & $\begin{array}{l}\text { McDonald \& } \\
\text { Kennedy } 30\end{array}$ & $\uparrow$ \\
\hline & 1,486 & United States & Mexico and Non-Mexico & Spanish & Roman Catholicism & $\begin{array}{l}\text { Albrecht et al. } \\
\qquad 18 * \star\end{array}$ & $\leftrightarrow$ \\
\hline & 399 & United States & "Mainly Mexican" & Spanish & Roman Catholicism & Ulmann et al. 84 & $\uparrow$ \\
\hline & 1,610 & United States & Mexico & Spanish & Roman Catholicism & Creighton et al. 27 & $\uparrow$ \\
\hline & 273,188 & United States & * & * & * & Park et al. 19 & $\uparrow$ \\
\hline & 43,042 & United States & Mexico & Spanish & Roman Catholicism & Riosmena et al. 85 & $\leftrightarrow$ \\
\hline & \multicolumn{6}{|c|}{ Number of mentions finding positive association/Total number of mentions } & $15 / 19$ \\
\hline
\end{tabular}

(continues)

that this variable had a significant effect on the prevalence of cardiovascular risk factors (including overweight) among immigrants. A study by Martin-Fernandez et al. 37 of immigrants living in France found that the association between length of time spent in the host country and BMI/overweight was only evident among older men.

\section{- Hispanics}

Nineteen mentions of the Hispanic subgroup involving different countries of origin were made in 17 studies, of which 15 showed a positive associa- tion between length of residence and $\mathrm{BMI} /$ rate of overweight $79 \%$ ). All except one of the studies (from Canada) were from the United States. Sample sizes varied between 32 and 273,188 immigrants.

A cross-sectional population based study carried out by Sanchez-Vaznaugh et al. 29 in California showed that increases in BMI with length of residence and general mean $\mathrm{BMI}$ were greatest among Hispanic immigrants. This association varies within the Hispanic subgroup, with Mexicanimmigrants experiencing thegreatestincrease in BMI and waist circumference over time 18 . 
Table 2 (continued)

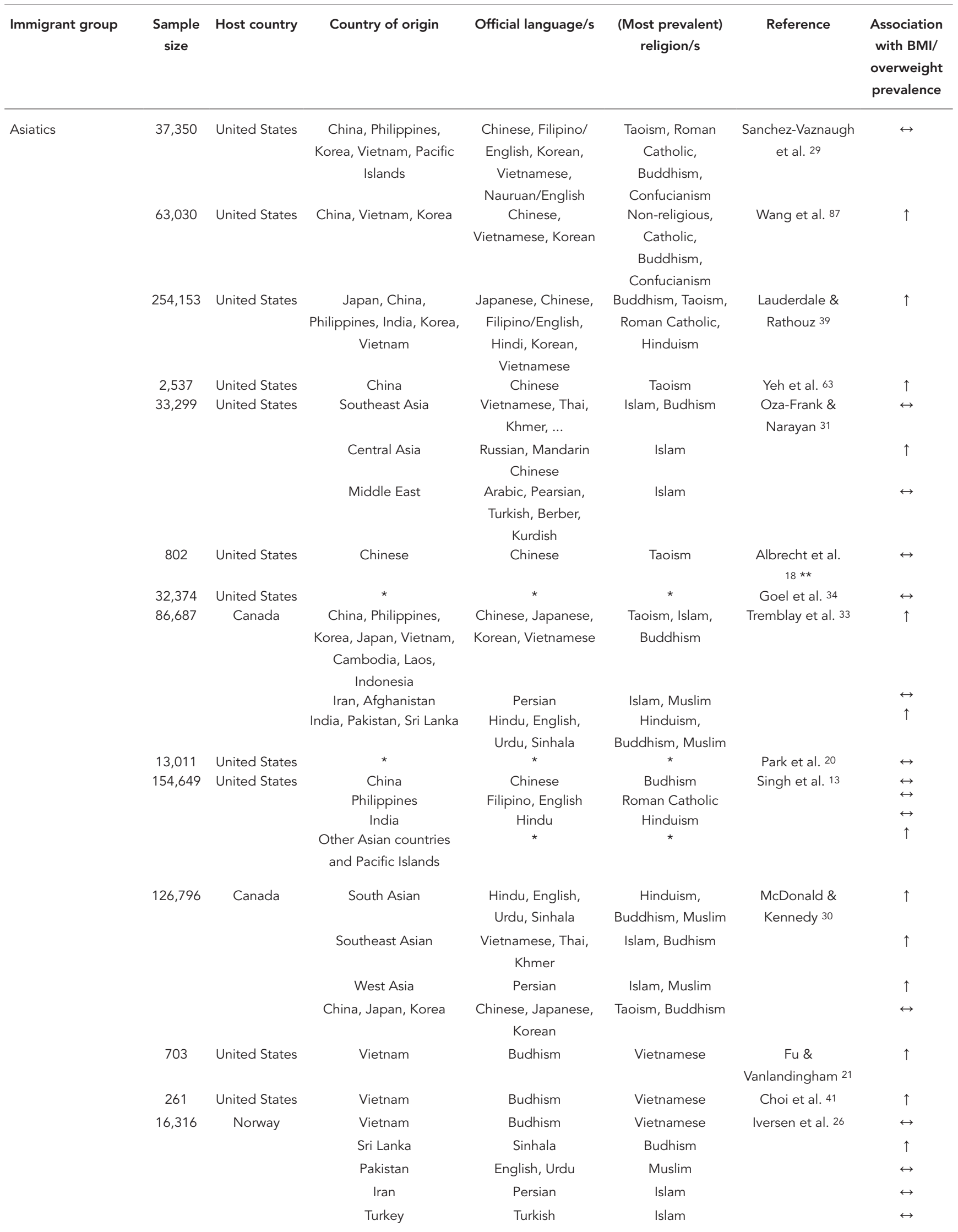

(continues) 
Table 2 (continued)

\begin{tabular}{|c|c|c|c|c|c|c|c|}
\hline Immigrant group & $\begin{array}{l}\text { Sample } \\
\text { size }\end{array}$ & Host country & Country of origin & Official language/s & $\begin{array}{c}\text { (Most prevalent) } \\
\text { religion/s }\end{array}$ & Reference & $\begin{array}{c}\text { Association } \\
\text { with BMI/ } \\
\text { overweight } \\
\text { prevalence }\end{array}$ \\
\hline \multirow[t]{7}{*}{ Asiatics } & 1,384 & Netherlands & Turkey & Turkish & Islam & $\begin{array}{c}\text { Dijkshoorn et } \\
\text { al. } 42\end{array}$ & $\leftrightarrow$ \\
\hline & 3,228 & United States & India & Hindu & Hinduism & Bharmal et al. 40 & $\leftrightarrow$ \\
\hline & 163,797 & Canada & South Asian & $\begin{array}{l}\text { Vietnamese, Thai, } \\
\text { Khmer, Hindu, ... }\end{array}$ & $\begin{array}{l}\text { Islam, Budhism, } \\
\text { Hinduism }\end{array}$ & Chiu et al. 35 & $\leftrightarrow$ \\
\hline & & & China & Chinese & Budhism & & $\leftrightarrow$ \\
\hline & 517 & United States & China & Chinese & Budhism & Parikh et al. 86 & $\leftrightarrow$ \\
\hline & 100 & $\begin{array}{l}\text { United } \\
\text { Kingdom }\end{array}$ & South Asian & $\begin{array}{l}\text { Vietnamese, Thai, } \\
\text { Khmer, Hindu, ... }\end{array}$ & $\begin{array}{l}\text { Islam, Budhism, } \\
\text { Hinduism }\end{array}$ & $\begin{array}{c}\text { Garduño-Diaz \& } \\
\text { Khokhar } 24\end{array}$ & $\leftrightarrow \leftrightarrow^{\star \star \star}$ \\
\hline & \multicolumn{6}{|c|}{ Number of mentions finding positive association/Total number of mentions } & $13 / 34$ \\
\hline \multirow[t]{12}{*}{ Europeans } & 37,350 & United States & * & * & * & $\begin{array}{c}\text { Sanchez-Vaznaugh } \\
\text { et al. } 29\end{array}$ & $\downarrow$ \\
\hline & 33,299 & United States & * & * & Christian & Oza-Frank \& & $\uparrow$ \\
\hline & & & Russia & Russian & $\begin{array}{l}\text { Orthodox } \\
\text { Christianity }\end{array}$ & Narayan 31 & $\uparrow$ \\
\hline & 126,796 & Canada & * & * & * & $\begin{array}{c}\text { McDonald \& } \\
\text { Kennedy } 30\end{array}$ & $\uparrow$ \\
\hline & 32,374 & United States & * & * & * & Goel et al. 34 & $\uparrow$ \\
\hline & 86,687 & Canada & * & * & * & Tremblay et al. 33 & $\uparrow$ \\
\hline & 13,011 & United States & * & * & * & Park et al. 20 & $\uparrow$ \\
\hline & 154,649 & United States & * & * & * & Singh et al. 13 & $\uparrow$ \\
\hline & 843 & Luxembourg & Portugal & Portuguese & Roman Catholic & Alkerwi et al. 22 & $\leftrightarrow$ \\
\hline & 218 & United States & Former Soviet Union & Russian & $\begin{array}{l}\text { Orthodox } \\
\text { Christianity }\end{array}$ & Miller et al. 16 & $\leftrightarrow$ \\
\hline & 163,797 & Canada & * & * & * & Chiu et al. 35 & $\uparrow$ \\
\hline & \multicolumn{6}{|c|}{ Number of mentions finding positive association/Total number of mentions } & $8 / 11$ \\
\hline \multirow[t]{3}{*}{ North Africans } & 1,384 & Netherlands & Morocco & Arabic, Berber & Muslim & $\begin{array}{c}\text { Dijkshoorn et } \\
\text { al. } 42\end{array}$ & $\uparrow$ \\
\hline & 339 & Italy & Morocco & Arabic, Berber & Muslim & Toselli et al. 53 & $\uparrow$ \\
\hline & \multicolumn{6}{|c|}{ Number of mentions finding positive association/Total number of mentions } & $2 / 2$ \\
\hline \multirow[t]{10}{*}{ Africans } & 37,350 & United States & * & * & * & $\begin{array}{c}\text { Sanchez-Vaznaugh } \\
\text { et al. } 29\end{array}$ & $\uparrow$ \\
\hline & 33,299 & United States & * & * & * & Oza-Frank et al. 31 & $\uparrow$ \\
\hline & 126,796 & Canada & * & * & * & $\begin{array}{c}\text { McDonald \& } \\
\text { Kennedy } 30\end{array}$ & $\uparrow$ \\
\hline & 32,374 & United States & * & * & * & Goel et al. 34 & $\leftrightarrow$ \\
\hline & 13,011 & United States & * & * & * & Park et al. 20 & $\leftrightarrow$ \\
\hline & 154,649 & United States & * & * & * & Singh et al. 13 & $\leftrightarrow$ \\
\hline & 53 & Israel & Ethiopia & Amharic & Christianity & $\begin{array}{c}\text { Regev-Tobias et } \\
\text { al. } 12\end{array}$ & $\uparrow$ \\
\hline & 208 & Norway & Somalia & Somali, Arabic & Muslim & $\begin{array}{l}\text { Gele \& Mbalilaki } \\
\qquad 23\end{array}$ & $\uparrow$ \\
\hline & 163,797 & United States & * & * & * & Chiu et al. 35 & $\leftrightarrow$ \\
\hline & \multicolumn{6}{|c|}{ Number of mentions finding positive association/Total number of mentions } & $5 / 9$ \\
\hline
\end{tabular}

* No indication (i.e., not possible to identify, from the original article/reference);

** Albrecht et al. 18 is the only longitudinal study included in this review;

*** There is no indication of the statistical significance of the increased BMI mean in long-term immigrants compared with short-term immigrants.

$\uparrow$ Significant statistical positive association between the two variables of interest; $\leftrightarrow$ No significant association found between the two variables of interest;

$\downarrow$ Statistical tendency (though not significant) for a negative association between the two variables of interest. 
Albretch et al. 18 conducted the only longitudinal study on this matter involving Asian and Hispanic immigrants living in six different regions of the United States. Mean annual changes in BMI were statistically significant among Mexican immigrants, but not in other Hispanic subgroups. However, these changes are not significantly different from those observed among US-born Mexican-Americans.

The findings suggest differences between genders. Barcenas et al. 38 reported that among males BMI was significantly in long-term immigrants (resident for $\geq 15$ years) than among shortterm immigrants ( $<5$ years), while among females BMI was significantly higher in all length of residence categories (5 to 9 years; 10 to 14 years; $\geq 15$ years) than in the short-term category 32 .

\section{- Asians}

Results were less consistent, showing differences according to region of birth. Sample sizes varied from 261 to 254,153 individuals. Studies covered the following host countries: United States (13), Canada (3), Norway (1), and the Netherlands (1). Of the 34 mentions made of the Asian subgroup (corresponding to 18 different studies about Asian immigrants), 13 (38.2\%) found a positive and significant association between length of residence and $\mathrm{BMI} /$ rate of overweight. McDonald et al. 30 found that there was little change in weight with increasing length of residence in the host country among Chinese immigrants living in Canada. The only longitudinal study included in this review showed that there was no increase in BMI or waist circumference among Chinese immigrants after a five-year follow-up 1 , while three studies 1,13,39 found a low prevalence of overweight in this group. Evidence from two studies 30,31 shows a positive or null association between the two main variables among immigrants from the Middle East and West Asia. While no increase in BMI with increasing length of residence in the host country was shown for Indians living in California ${ }^{40}$, BMI and insulin-resistance tends to be greater in this group than in their counterparts living in India 10. A positive association between increase in BMI and increasing length of residence in the host country was found among Vietnamese immigrants living in United States 21,41 and this group was more likely to be overweight than returnees or counterparts who never left the country 21 . This effect was not confirmed in Norway 26. Dijkshoorn et al. 42 found a high prevalence of obesity in Turkish immigrants living in the Netherlands, but there was no evidence of an association with length of residence in the host country.

\section{- Europeans}

Sample sizes varied between 218 and 163,797. Only two studies included the immigrants' country of origin 16,22. Eleven mentions were made of the European subgroup in 10 different studies, of which eight reported a positive association between the two variables of interest $(72.7 \%)$.

A cross-sectional population-based study in the United States carried out by SanchezVaznaugh et al. ${ }^{29}$ reported that the BMI of immigrants living in the host country for less than 5 years was $1.6 \%$ higher than that of immigrants who had been living in the country for 15 years or more. However, the authors also found that the BMI of white immigrants living in United States for 15 years was higher than the BMI of those who had lived in the country for 10 to 14 years. These results contradict the findings of a cross-sectional population-based study carried out in the United States by Oza-Frank et al. 31 which shows that long-term Caucasian immigrants (resident for $\geq 15$ years) are three-times more likely to be overweight than recent immigrants (resident for $<5$ years) from the same ethnic background. Newly-arrived Caucasian immigrants in Canada are $15 \%$ less likely to be overweight but the rate of overweight progressively increases reaching host country levels after around 30 years of residence 30 .

\section{- Africans}

Two studies included North Africans (Moroccans). The host countries were the Netherlands and Italy and sample sizes were 339 and 1,384 Both studies found a significant positive association between the two variables of interest. However, the study in the Netherlands, carried out by Dijkshoorn et al. ${ }^{42}$, found that this association was only statistically significant among women (cross-sectional study with data derived from a sample taken from the Amsterdam population register).

The sample sizes of Sub-Saharan African immigrants varied between 208 and 163,797 and covered the following host countries: United States (6), Canada (1), Israel (1); and Norway (1). Nine mentions were made in nine different studies, five of which reported a positive and significant association between length of residence and $\mathrm{BMI} /$ rate of overweight (55.6\%). Only two studies reported the nationality of immigrants (Ethiopia and Somalia). A significant increase in the rate of overweight with increasing length of residence was found among Somali immigrants living in Oslo (Norway) 23. 
Comparison of immigrants with respective home-country residents

Of the six studies found in this category, four were from European countries and two from Australia (Table 3). Sample sizes ranged from 25043 to 2,000 44 and the papers were published between 199545 and 2011 44. All samples included both genders. Two studies 43,45 used relatives as controls. Five of the studies $45,46,47,48,49$ reported that immigrants had a higher BMI than the control group. A study of Indian immigrants living in Australia 43 showed no significant difference in BMI among men. However, the group living in India had higher waist-hip ratios. Two studies 43,46 showed that the cardiovascular risk profile was better in immigrants than in the control group.

Five out of the six studies included Asian samples. Two studies 43,46 of Indian and Sri Lankan immigrants reported that the cardiovascular risk profile was worse in nonimmigrants, despite the fact that BMI was lower or equal in this group. Mahajan \& Bermingham 43 found that the level of abdominal obesity was lower (waist-hip ratio) among Indian immigrants than among men and women living in the country of origin. Tennakoon et al. 46 found that female Sri Lankan immigrants had higher BMI and higher waist circumference, but lower triglyceride and blood pressure levels than women living in Sri Lanka, while Bhatnagar et al. 45 reported worse cardiovascular profiles, higher BMI values, and higher total cholesterol levels among Indians living in England when compared to their counterparts living in India.

Kouris-Blazo et al. 50 reported that the rate of obesity among elderly Greek immigrants liv- ing in Australia was higher than among their counterparts in Greece. These immigrants apparently had healthier food habits but a worse health status.

\section{Discussion}

The association between length of residence in the host country and increase in BMI seems to vary according to the ethnic background of immigrants. This section therefore takes a more detailed look at the association by ethnic group.

\section{Hispanics}

The risk of developing obesity is greater among Hispanic immigrants than among people from other ethnic groups living in the United States 29. The results of linear regression show a clear increase in mean BMI across generations of Hispanic immigrants 10 . This increase is greater among female immigrants 38 , showing that women are more vulnerable to the acculturation process 28 .

High rates of prevalence of obesity and type 2 diabetes among Hispanics may be explained by the genetic heritage received from American Indians 10. Sanchez-Vaznaugh et al. 29 explain that newly-arrived Hispanic immigrants have lower educational attainment and are less likely to speak English, stalling upward social mobility and constraining life choices and opportunities. Furthermore, higher BMI may be due to cumulative exposure to social and physical environments and neighborhoods that lack access

Table 3

Body mass index (BMI) or overweight prevalence comparisons between immigrant and non-immigrant communities, by host country.

\begin{tabular}{|c|c|c|c|c|}
\hline $\begin{array}{l}\text { Immigrant } \\
\text { group }\end{array}$ & Host country & Year of publication & Reference & Significant differences (immigrant group vs. their counterparts) \\
\hline Pakistani & Norway & 2011 & 44 & $\begin{array}{l}\text { Men: immigrants had significantly higher BMI }\left(4.5 \mathrm{~kg} / \mathrm{m}^{2} \text { higher in immigrant }\right. \\
\text { group); Women: immigrants had significantly higher BMI }\left(3.3 \mathrm{~kg} / \mathrm{m}^{2} \text { higher in }\right. \\
\text { immigrant group) }\end{array}$ \\
\hline \multirow[t]{3}{*}{ Indians } & Norway & 2011 & 44 & $\begin{array}{l}\text { Men: BMI without significant differences between groups; } \\
\text { Women: immigrants had significantly higher BMI }\left(2.6 \mathrm{~kg} / \mathrm{m}^{2}\right)\end{array}$ \\
\hline & United Kingdom & 2006 & 47 & $\begin{array}{l}\text { Men: immigrants had significantly higher BMI }\left(4.9 \mathrm{~kg} / \mathrm{m}^{2}\right) ; \\
\text { Women: immigrants had significantly higher BMI }\left(5.8 \mathrm{~kg} / \mathrm{m}^{2}\right)\end{array}$ \\
\hline & United Kingdom & 1995 & 45 & $\begin{array}{l}\text { Men: immigrants had significantly higher BMI }\left(3.9 \mathrm{~kg} / \mathrm{m}^{2}\right) ; \\
\text { Women: immigrants had significantly higher BMI }\left(4.7 \mathrm{~kg} / \mathrm{m}^{2}\right)\end{array}$ \\
\hline Sri Lankans & Norway & 2010 & 46 & $\begin{array}{l}\text { Men: immigrants had significantly higher BMI }\left(3.2 \mathrm{~kg} / \mathrm{m}^{2}\right) \\
\text { Women: immigrants had significantly higher BMI }\left(2.1 \mathrm{~kg} / \mathrm{m}^{2}\right)\end{array}$ \\
\hline Greeks & Australia & 1996 & 48 & \\
\hline
\end{tabular}


to nutritious food, promote the consumption of high-density foods and constrain physical activity. This is a relevant aspect considering that Hispanics tend to be from more socioeconomically disadvantaged backgrounds than other migrant groups 20 . The effect of the neighborhood factor can be so significant that some studies recommend it as a better measure of the socioeconomic status of Hispanic immigrants 47 .

Cuban and Puerto Rican long-term immigrants living in United States were the only groups where the risk of being overweight did not increase ${ }^{13}$. Albrecht et al. 18 suggest that the impact of acculturation varies within the Hispanic subgroup. However, their study was the only longitudinal study found in our review and found no significant increase in BMI in Hispanic subgroups over a five-year follow up period, except in Mexicans where significant increases in BMI and waist circumference were observed. This increase is not significantly different from the one observed in Mexican-Americans born in the United States. Hispanics of Mexican origin often adopt negative health behaviors and are likely to be influenced by behaviors established in the country of origin. The study sample was relatively small and the cohort was relatively older and healthier and was sampled from selected regions, which may compromise the generalizability of the results. A study carried out by Park et al. 19 revealed that the rate of obesity among Hispanic immigrants in the United States increases with increasing length of residence, but does not reach the levels of the population born in the United States, and, according to Park et al. 19 , obesity rates among Hispanic immigrants increase at a slower rate than in the native population. Park et al. 19 highlight the following reasons behind the misleading conclusions about obesity among immigrants: differences in aging between immigrants and the native population, the growing duration of the immigration trend and historical trends in obesity. All studies of Hispanic immigrants were conducted in the United States and Canada. Therefore, there is no evidence to suggest that the same increases in BMI and rates of overweight with increasing length of residence would be experienced by Hispanic immigrants in other host countries.

\section{Asians}

The analysis of this group is more challenging since the association between length of residence in the host country and BMI varies greatly according to the region of birth, which was not always described in the papers. Asian immigrants living in the United States seem to be the ethnic group that is least affected by acculturation 17,34. Researchers have suggested that this may be due to the fact that Asians are more likely to have higher educational attainment than Hispanics and are more likely to live in better neighborhoods, which in turn influences access to nutritious food 29. The evidence related to Middle East or West Asian immigrants is too scarce to make any firm conclusions. There is a positive association between BMI and rates of overweight with increasing length of residence among Vietnamese immigrants living in the United States, but not among those living in Norway. This suggests that the host country may be an important factor influencing the direction and strength of the association. Furthermore, the BMI of immigrants fluent in Norwegian is lower than in the native population, suggesting that greater acculturation is a protective factor for weight increase in this group 26. Comparative studies with samples of Asian immigrants showed mixed results. While Mahajan \& Bermingham 43 and Tennakoon et al. 46 reported a better cardiovascular risk profile in immigrants living in Sydney (Australia) and Oslo, respectively, Bhatnagar et al. 45 found the opposite in immigrants living in England. The first study had several limitations. The sample was composed of a small number of qualified professionals $(n=125)$, which may have influenced results. All the same, these differences may indicate a more pronounced change in food habits, caloric intake and, potentially, saturated fat intake in England. Tennakoon et al. 46 conducted their study with Sri Lankan immigrants living in Oslo and, according to the authors, the higher BMI in women living in Sri Lanka may be explained by the lack of availability of specific foods in Norway, where, despite increasing BMI among the native population, cardiovascular diseases have decreased with improvements in diet quality from the last 30 years. However, methodological limitations of this study included a gap of three years between the measurements of each sample group and the use of different methodologies to measure blood pressure, and a low response rate conditioned by educational level.

\section{Europeans}

The studies of European immigrants lack information regarding the country of origin, making it difficult to interpret the results. SanchezVaznaugh et al. ${ }^{29}$ reported a decrease in BMI with increasing duration of residence of immigrants in the United States which, according to the authors, may be explained by the fact that Caucasian immigrants are often more likely to speak English and to live in better neighbour- 
hoods than Hispanic immigrants, which in turn leads to greater access to healthy food and facilitates transition into the host country. In Canada, rates of obesity are more likely to reach the same levels as the native population among Caucasian immigrants than in non-Caucasian immigrants. It has been suggested that ethnic minority immigrants acculturate more slowly than those from educated urban settings with similar physical characteristics (such as skin color) 51. Also, Caucasian immigrants are more likely to speak English, therefore suggesting that linguistic isolation is not a predictor of BMI 51 . An increase in the proportion immigrants in the neighborhood was associated with lower BMI, suggesting that living in a predominantly immigrant neighborhood is a protective factor for this group 20. One comparative study reported that obesity rates were higher among Greek immigrants than among their counterparts living in their home country. Greek immigrants living in Australia in the 1980s seemed to be living in a "morbidity-mortality paradox": despite high levels of obesity and physical inactivity, data from the time shows that this population group had the second highest average life expectancy, even greater than that of their counterparts in Greece. This paradox has been explained by the adherence to the traditional Mediterranean diet 52 . However Kouris-Blazo et al. 50 did not confirm this protective effect, possibly due to changes in the original Mediterranean diet or greater exposure to the Australian diet.

\section{North Africans}

Studies concerning North African immigrants are scarce but unanimous. Toselli et al. 53 and Dijkshoorn et al. 42 showed an increase in BMI in immigrants living in Italy for over 12 years. These studies also reported a significant increase in stress-related factors and the desire to return home among North Africans living in Italy 53 Acculturative stress has been observed by other studies and can lead to a lowered mental health status (particularly depression and anxiety) that is a known risk factor for obesity. Moroccan families generally fall into lower income categories because of their level of education and professional training 54 , which is often associated with higher rates of obesity 55. In the Netherlands, macronutrient intake among Turkish and Moroccan immigrants was satisfactory, while micronutrient intake was inadequate, leading to differences in weight and health status 54 .

\section{Sub-Saharan Africans}

Black immigrants often gain weight during the acculturation process. However, not all the studies observed a significant association between the two variables 20,34 . There was a dramatic increase in rates of overweight with length of residence in the host country among Sub-Saharan African immigrants living in Canada 12,30 and Israel. This ethnic group is also susceptible to dietrelated illnesses such as cardiovascular disease, hypertension, diabetes mellitus, obesity, and certain cancers 56 . BMI and obesity and insulin resistance prevalence rates tend to be higher among Africans living in the United States than in those living in their home country despite similar genetic origin, showing that differences in chronic disease prevalence are probably due to environmental factors 10. Often, newly-arrived African immigrants are malnourished and have health problems 57 which can influence their understanding of food and weight. Studies have shown racial differences on weight misperception. For example, overweight and obese African men are more likely to misperceive their own weight status than men from other ethnic backgrounds 58 Unhealthy practices in African-American communities have been attributed to limited neighborhood healthy food availability and the high cost of healthy food, black consumer-oriented marketing, food preferences and eating patterns 56. Cultural eating patterns are considered a barrier to healthy eating 48 and deviation from mainstream dietary guidelines in United States is greatest among African-Americans 59. Several studies indicate that the connections made with family and community through food are highly valued by African Americans 60. Dietary changes therefore unavoidably entail cultural loss, and resistance towards following healthy eating guidelines may be seen as a form of resistance to racism or cultural dominance 56 .

Immigration involves a number of changes in lifestyle, culture and socioeconomic status (at individual, family, and community level) for both immigrants and host populations. Understanding the links between immigration and health is a major epidemiological and public health challenge. The main goal of this article was to summarise current knowledge regarding the impact of immigration on the evolution of body mass index which is recognized as an important health indicator.

Major methodological differences between the studies reviewed made the direct comparison and interpretation of results very difficult, if not impossible, in some cases. Furthermore, a relatively large proportion of the literature analysed 
by this study did not provide sufficient information about methodological aspects, particularly sampling procedures, recoding of data and statistical details. A consensual definition of sample selection criteria for studies involving immigrant groups is important to facilitate a better understanding of results and the interpretation and comparison of findings from different studies.

One of the limitations of our study is the noninclusion of grey literature. Unpublished master's and doctoral theses and reports are a possible further source of detailed information about this issue.

Stratification of data by gender is also important due to different health behaviors adopted by men and women throughout the immigration process 28 . Women are generally considered more vulnerable to the acculturation process than men and consequently are more susceptible to being overweight than men ${ }^{8}$. It is also important to study morbidity differences according to gender, ethnic background and age 61,62. Cultural preferences, such as media usage 63 , and other indicators are often used to measure acculturation instead of, or in addition to, length of residence in the host country.

Figure 2 shows several variables that may mediate the impact of immigration on health. The process is layered and variables are interdependent.

- Ecogenetics: most chronic diseases are a result of the interaction between genetic susceptibility to a particular disease and environmental factors. The data on immigrants suggests that this interaction affects the development of type 2 diabetes 64 . Rapid changes in diet and lifestyle can influence the heritability of different phenotypes, which are dependent on the nutritional environment for their expression 10.

- Socioeconomic status and psychosocial factors: immigrants generally come from developing countries or a disadvantaged background. Immigration may lead to greater food availability and/or purchasing power. Employment can also be an important factor, since an employed person has less free time to purchase and prepare local food. Immigrants are more likely to work longer hours and have two or more jobs to support themselves 65 . Members of younger and bigger households are also more likely to choose convenience food, while older households are more likely to maintain traditional meals 66. Immigrants report that acculturation is often associated with an increase in stress 69,70,71 and stress and stress-related disorders may play an important role in the development of obesity 67,68 .

- Traditions and religion: African-Caribbean groups consume herbal teas and a specific veg- etable which they believe relieves hypertension and diabetes. Dietary, cultural and religious norms may also play an important role in shaping eating habits. African-Caribbean subgroups often do not eat animal-based foods because they are seen as "dead food". The Seventh-day Adventists and South Asians also have dietary restrictions according to their specific religious beliefs 5 .

- Cultural adaptation: an immigrant's status in the country (documented versus undocumented) 72 , first language, media preferences, and level of identification with host country culture are important acculturation mediators (and may also be barriers to accessing health services 73) and are often factors associated with increases in BMI after immigration.

- Body image, self-perception and beliefs relating to food: body image is often rooted in the culture of the immigrant's home country. For example, being overweight may be seen as sign of success by some cultures, rather than as a health problem. In Moroccan communities, obesity is perceived as sign of prosperity among women $74,75,76$

- Nutrition transition: following migration, ethnic groups alter their eating habits, combining elements of their traditional diet with some of the less healthy aspects of the Western diet. Some studies showed an increase in fat and sugar intake and a decrease in fruit and vegetable consumption after immigration 77 , while others observed a decrease in vegetarianism and an increase in the consumption of caffeinated beverages 24 . Food availability and prices are determinants of food choices among immigrants 70 , while the factors age and generation are two major determinants of the extent of dietary change 5 .

- Physical inactivity: physical activity levels are more likely to be lower among immigrant groups than in white or nonimmigrant groups 49 . This may be related to the known influence of socioeconomic factors on physical activity. New immigrants often have lower socioeconomic status and work longer hours than nonimmigrants, which reduces the amount of time available and opportunities to practice physical activity 49 . Nevertheless, some immigrants state being more physically active after immigration 8 .

\section{Conclusion}

We found only five literature reviews of the effect of immigration on weight gain: four specifically addressed the epidemiology of obesity among immigrants living in the United States, and one, conducted by Misra \& Ganda 10 and published 

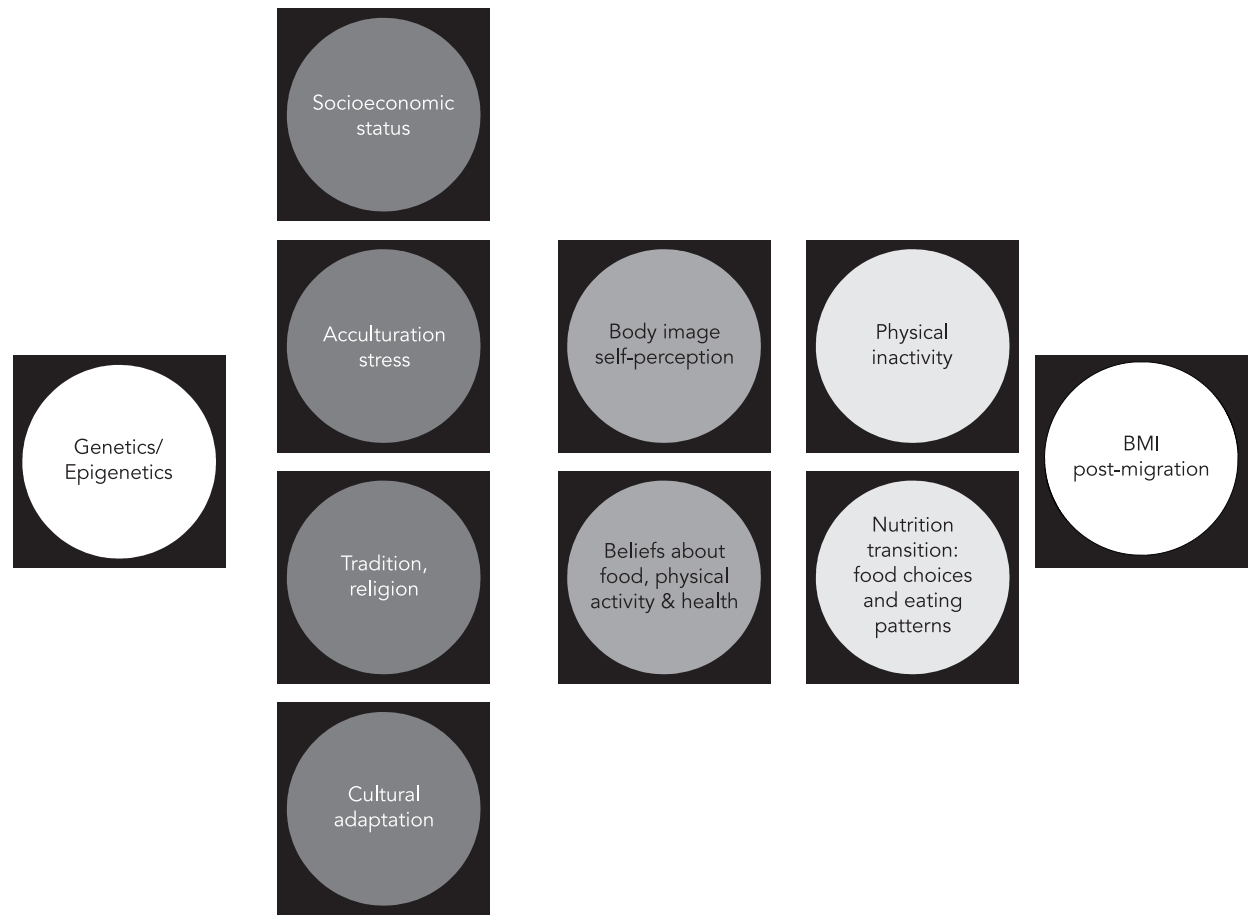

BMI: body mass index.

in 2007, focused on adiposity and diabetes in ethnic groups. The present study aimed to carry out a worldwide review and clearly focus on comparable research in this field in order to provide a qualitative synthesis of current data and an updated perspective on this topic. The flux of immigrants has changed since 2007 and this is an important factor to consider when analysing and interpreting data. Notwithstanding the methodological differences, the most relevant conclusion of these studies is that there is a significant and positive relationship between body weight and length of residence among U.S. immigrants 8 . This association varies according to ethnic background and may be weaker or inexistent among immigrants with a higher level of education 78 , and BMI tends to converge towards the levels of the host population at a quicker rate among women immigrants 79 .

Studies about the impact of immigration on health present several challenges due to the number of variables involved and constant changes in these factors. First, migrant populations may not comprise a representative sample of their home country's population and may be healthier or unhealthier than their nonimmigrant counterparts 10 . Secondly, the increased influence of the Western food industry is radically affecting the diet of children and teenagers in several underdeveloped countries and therefore the eating habits commonly seen in first generation immigrants may also have been acquired by their nonimmigrant counterparts in their home country ${ }^{10}$. All but one of the studies covered by this review are cross-sectional, making it hard to make causal inferences about the length of residence in the host country and the increase in BMI and prevalence of overweight. This is a significant drawback and therefore further research of this association involving longitudinal studies of immigrants from different ethnic backgrounds is necessary. Nevertheless, some important conclusions can be drawn from these studies. Acculturation, often measured as length of residence in the host country, is an important determinant of the health of immigrants whose effect depends on a number of variables which have major implications for nutrition transition. 
Whereas in some countries immigrants have a lower risk of obesity than the home country population (for example the United States), in other countries the risk of obesity among immigrants is apparently greater (for example Sweden). Therefore, the cultural aspects of the host country seem to play a key role in health protection. Despite these differences, the impact of acculturation is often negative and generally the risk of obesity among immigrants increases as length of residence in the host country increases. Furthermore, nonimmigrants tend to have a lower mean BMI than their counterparts who decided to immigrate. Understanding the culture, beliefs and traditions of the country of origin, as well as food acculturation, may be the key to a better understanding and preventing the negative impacts of this process.

\section{Resumen}

La obesidad puede ser una de las características más variables en el proceso de migración. En este estudio se pretendieron actualizar los conocimientos acerca de la relación entre migración e índice de masa corporal (IMC). Además, se procedió a una revisión sistemática de la literatura, de acuerdo con las directrices PRISMA, por búsqueda electrónica (actualizada en agosto de 2014). Se incluyeron 39 artículos y se analizaron cualitativamente. Los resultados variaron según el grupo étnico, el país de origen y acogida. Los inmigrantes hispanos, africanos y europeos mostraron una relación consistente y positiva entre el IMC y el tiempo de migración. Los inmigrantes asiáticos mostraron una asociación positiva en menos de la mitad de los estudios. Puede haber un efecto negativo de la migración sobre el IMC. Cambios nutricionales y de actividad física, factores psicosociales y la susceptibilidad genética pueden ser razones subyacentes que deben ser incluidas como variables moderadoras en estudios futuros.

Migración Internacional; Aculturación; Obesidad

\section{Contributors}

All authors made an equal contribution to the production of this article. 
1. Lv N, Cason KL. Dietary pattern change and acculturation of Chinese Americans in Pennsylvania. J Am Diet Assoc 2004; 104:771-8.

2. Méjean C, Traissac P, Eymard-Duvernay S, Delpeuch F, Maire B. Influence of acculturation among Tunisian migrants in France and their past/ present exposure to the home country on diet and physical activity. Public Health Nutr 2008; 12: 832-41.

3. Ayala G, Baquero B, Klinger S. A systematic review of the relationship between acculturation and diet among latinos in the United States: implications for future research. J Am Diet Assoc 2008; 108:1330-44.

4. Satia JA. Dietary acculturation and the nutrition transition. Appl Physiol Nutr Metab 2010; 35: 219-23.

5. Gilbert PA, Khokhar S. Changing dietary habits of ethnic groups in Europe and implications for health. Nutr Rev 2008; 66:203-15.

6. Sáez PPM, Cantero AMT, Isasa MET. La alimentación de los inmigrantes marroquíes de la Comunidad de Madrid: factores que influyen en la selección de los alimentos. Aten Primaria 2001; 27: 264-70.

7. Argeseanu Cunningham S, Ruben JD, Narayan KMV. Health of foreign-born people in the United States: a review. Health Place 2008; 14:623-35.

8. Oza-Frank R, Cunningham S. The weight of US residence among immigrants: a systematic review. Obes Rev 2010; 11:271-80.

9. World Health Organization. Obesity: preventing and managing the global epidemic. Geneva: World Health Organization; 2000. (Technical Report Series, 894).

10. Misra A, Ganda OP. Migration and its impact on adiposity and type 2 diabetes. Nutrition 2007; 23:696-708.

11. Moher D, Liberati A, Tetzlaff J, Altman DG. Preferred reporting items for systematic reviews and meta-analyses: the PRISMA statement. BMJ 2009; 339:b2535.

12. Regev-Tobias H, Reifen R, Endevelt R, Havkin O, Cohen E, Stern G, et al. Dietary acculturation and increasing rates of obesity in Ethiopian women living in Israel. Nutrition 2012; 28:30-4.

13. Singh GK, Siahpush M, Hiatt R, Timsina LR. Dramatic increases in obesity and overweight prevalence and body mass index among ethnic-immigrant and social class groups in the United States, 1976-2008. J Community Health 2011; 36:94-110.

14. Wolin KY, Colangelo LA, Chiu BC, Gapstur S. Obesity and immigration among latina women. J Immigr Minor Health 2009; 11:428-31.

15. Himmelgreen DA, Pe R, Martinez D, Bretnall A, Eells B. The longer you stay, the bigger you get: length of time and language use in the U.S. are associated with obesity in Puerto Rican women. Am J Phys Anthropol 2004; 125:90-6.

16. Miller AM, Chandler PJ, Wilbur J, Sorokin O. Acculturation and cardiovascular disease risk in midlife immigrant women from the former Soviet Union. Prog Cardiovasc Nurs 2004; 19:47-55.
17. Roshania R, Narayan KM, Oza-Frank R. Age at arrival and risk of obesity among US immigrants. Obesity (Silver Spring) 2008; 16:2669-75.

18. Albrecht SS, Diez Roux AV, Kandula NR, Osypuk TL, Ni H, Shrager S. Immigrant assimilation and BMI and waist size: a longitudinal examination among Hispanic and Chinese participants in the multi-ethnic study of atherosclerosis. Obesity (Silver Spring) 2013; 21:1695-703.

19. Park J, Myers D, Kao D, Min S. Immigrant obesity and unhealthy assimilation: alternative estimates of convergence or divergence, 1995-2005. Soc Sci Med 2009; 69:1625-33.

20. Park Y, Neckerman KM, Quinn J, Weiss C, Rundle A. Place of birth, duration of residence, neighborhood immigrant composition and body mass index in New York City. Int J Behav Nutr Phys Act 2008; 5:1-11.

21. Fu H, Vanlandingham MJ. Disentangling the effects of migration, selection and acculturation on weight and body fat distribution: results from a natural experiment involving Vietnamese Americans, returnees, and never-leavers. J Immigr Minor Health 2012; 14:786-96.

22. Alkerwi A, Sauvageot N, Pagny S, Beissel J, Delagardelle C, Lair M-L. Acculturation, immigration status and cardiovascular risk factors among Portuguese immigrants to Luxembourg: findings from ORISCAV-LUX study. BMC Public Health 2012; 12:864.

23. Gele A, Mbalilaki AJ. Overweight and obesity among African immigrants in Oslo. BMC Res Notes 2013; 6:119.

24. Garduño-Diaz SD, Khokhar S. South Asian dietary patterns and their association with risk factors for the metabolic syndrome. J Hum Nutr Diet 2013; 26:145-55.

25. Fuentes-Afflick E, Hessol N. Acculturation and body mass among Latina women. J Womens Health 2008; 17:67-73.

26. Iversen T, Ma C-TA, Meyer HE. Immigrants' acculturation and changes in body mass index. Econ Hum Biol 2013; 11:1-7.

27. Creighton MJ, Goldman N, Pebley AR, Chung CY. Durational and generational differences in Mexican immigrant obesity: is acculturation the explanation? Soc Sci Med 2012; 75:300-10.

28. Koya DL, Egede LE. Association between length of residence and cardiovascular disease risk factors among an ethnically diverse group of United States immigrants. J Gen Intern Med 2007; 22: 841-6.

29. Sanchez-Vaznaugh EV, Kawachi I, Subramanian SV, Sánchez BN, Acevedo-Garcia D. Differential effect of birthplace and length of residence on body mass index (BMI) by education, gender and race/ ethnicity. Soc Sci Med 2008; 67:1300-10.

30. McDonald JT, Kennedy S. Is migration to Canada associated with unhealthy weight gain? Overweight and obesity among Canada's immigrants. Soc Sci Med 2005; 61:2469-81. 
31. Oza-Frank R, Narayan KMV. Effect of length of residence on overweight by region of birth and age at arrival among US immigrants. Public Health Nutr 2009; 13:868-75.

32. Gutiérrez-Fisac JL, Marín-Guerrero A, Regidor E, Guallar-Castillón P, Banegas JR, Rodríguez-Artalejo F. Length of residence and obesity among immigrants in Spain. Public Health Nutr 2010; 13 1593-8.

33. Tremblay MS, Pérez CE, Ardern CI, Bryan SN. Obesity, overweight and ethnicity. Health Rep 2005; 16:23-34.

34. Goel MS, McCarthy EP, Phillips RS, Wee CC. Obesity among US immigrant subgroups by duration of residence. JAMA 2004; 292:2860-7.

35. Chiu M, Austin PC, Manuel DG, Tu JV. Cardiovascular risk factor profiles of recent immigrants vs long-term residents of Ontario: a multi-ethnic study. Can J Cardiol 2012; 28:20-6.

36. Cairney J, Ostbye T. Time since immigration and excess body weight. Can J Public Health 1999; 90:120-4.

37. Martin-Fernandez J, Grillo F, Tichit C, Parizot I, Chauvin P. Overweight according to geographical origin and time spent in France: a cross sectional study in the Paris metropolitan area. BMC Public Health 2012; 12:937.

38. Barcenas CH, Wilkinson AV, Strom SS, Cao Y, Saunders KC, Mahabir S, et al. Birthplace, years of residence in the United States, and obesity among Mexican-American adults. Obesity (Silver Spring) 2007; 15:1043-52.

39. Lauderdale DS, Rathouz PJ. Body mass index in a US national sample of Asian Americans: effects of nativity, years since immigration and socioeconomic status. Int J Obes (Lond) 2000; 24:1188-94.

40. Bharmal N, Kaplan R, Shapiro MF, Kagawa-Singer M, Wong MD, Mangione CM, et al. The association of religiosity with overweight/obese body mass index among Asian Indian immigrants in California. Prev Med 2013; 57:315-21.

41. Choi JY, Hwang J, Yi J. Acculturation, body perception, and weight status among Vietnamese American students. J Immigr Minor Health 2011; 13:1116-24.

42. Dijkshoorn H, Nierkens V, Nicolaou M. Risk groups for overweight and obesity among Turkish and Moroccan migrants in The Netherlands. Public Health 2008; 122:625-30.

43. Mahajan D, Bermingham MA. Risk factors for coronary heart disease in two similar Indian population groups, one residing in India, and the other in Sydney, Australia. Eur J Clin Nutr 2004; 58:751-60.

44. Zahid N, Meyer HE, Kumar BN, Claussen B, Hussain A. High levels of cardiovascular risk factors among Pakistanis in Norway compared to Pakistanis in Pakistan. J Obes 2011; 2011:163749.

45. Bhatnagar D, Anand IS, Durrington PN, Patel DJ, Wander GS, Mackness MI, et al. Coronary risk factors in people from the Indian subcontinent living in west London and their siblings in India. Lancet 1995; 345:405-9.

46. Tennakoon S, Kumar BN, Nugegoda DB, Meyer HE. Comparison of cardiovascular risk factors between Sri Lankans living in Kandy and Oslo. BMC Public Health 2010; 10:654.
47. Khan LK, Sobal J, Martorell R. Acculturation, socioeconomic status, and obesity in Mexican Americans, Cuban Americans, and Puerto Ricans. Int J Obes Relat Metab Disord 1997; 21:91-6.

48. Hargreaves MK, Schlundt DG, Buchowski MS. Contextual factors influencing the eating behaviours of African American women: a focus group investigation. Ethn Health 2002; 7:133-47.

49. Lindström M, Sundquist J. Immigration and leisure-time physical inactivity: a population-based study. Ethn Health 2001; 6:77-85.

50. Kouris-Blazos A, Wahlqvist ML, Trichopoulou A, Polychronopoulos E, Trichopoulos D. Health and nutritional status of elderly Greek migrants to Melbourne, Australia. Age Ageing 1996; 25:177-89.

51. Setia MS, Quesnel-Vallee A, Abrahamowicz M, Tousignant P, Lynch J. Convergence of body mass index of immigrants to the Canadian-born population: evidence from the National Population Health Survey (1994-2006). Eur J Epidemiol 2009; 24:611-23.

52. Kouris-Blazos A. Morbidity mortality paradox of 1st generation Greek Australians. Asia Pac J Clin Nutr 2002; 11 Suppl 3:S569-75.

53. Toselli S, Galletti L, Pazzaglia S, Gualdi-Russo E. Two-stage study (1990-2002) of North African immigrants in Italy. Homo 2008; 59:439-52.

54. Brussard JH, van Erp-Baart MA, Brants HA, Hulshof KF, Löwik MR. Nutrition and health among migrants in The Netherlands. Public Health Nutr 2001; 4:659-64.

55. Dinsa GD, Goryakin Y, Fumagalli E, Suhrcke M. Obesity and socioeconomic status in developing countries: a systematic review. Obes Rev 2012; 13:1067-79.

56. Beagan BL, Chapman GE. Meanings of food, eating and health among African Nova Scotians: "certain things aren't meant for Black folk". Ethn Health 2012; 17:13-29.

57. Okafor M-TC, Carter-Pokras OD, Picot SJ, Zhan M. The relationship of language acculturation (English proficiency) to current self-rated health among African immigrant adults. J Immigr Minor Health 2013; 15:499-509.

58. Godino JG, Lepore SJ, Rassnick S. Relation of misperception of healthy weight to obesity in urban black men. Obesity (Silver Spring) 2010; 18:1318-22.

59. Kumanyika S. Nutrition and chronic disease prevention: priorities for US minority groups. Nutr Rev 2006; 64:9-14.

60. Ahye BA, Devine CM, Odoms-Young AM. Values expressed through intergenerational family food and nutrition management systems among African American women. Fam Community Health 2006; 29:5-16.

61. Madrigal L, Brady J, Raxter M. Obesity, hypertension, and migration: a meta-analysis of populations of the South Asian diaspora. Hum Biol 2011; 83:71-86.

62. Delavari M, Farrelly A, Renzaho A, Mellor D, Swinburn B. Experiences of migration and the determinants of obesity among recent Iranian immigrants in Victoria, Australia. Ethn Health 2013; 18:66-82. 
63. Yeh M-C, Fahs M, Shelley D, Yerneni R, Parikh NS, Burton D. Body weight and length of residence in the US among Chinese Americans. J Immigr Minor Health 2009; 11:422-7.

64. Ferreira SRG, Lerario DDG, Gimeno SG, Sanudo A, Franco LJ. Obesity dietary and central pattern adiposity in Japanese immigrants: role of the western dietary pattern. J Epidemiol 2002; 12:431-8.

65. Fernandes A, Miguel JP, editors. Health and migration in the European Union: better health for all in an inclusive society. Lisbon: Institute of National Health Doutor Ricardo Jorge; 2009.

66. Arandia G, Nalty C, Sharkey JR, Dean WR. Diet and acculturation among Hispanic/Latino older adults in the United States: a review of literature and recommendations. J Nutr Gerontol Geriatr 2012; 31:16-37.

67. Hsieh SD, Muto T, Murase T, Tsuji H, Arase Y. Association of short sleep duration with obesity, diabetes, fatty liver and behavioral factors in Japanese men. Intern Med 2011; 50:2499-502.

68. Tseng M, Fang C. Stress is associated with unfavorable patterns of dietary intake among female chinese immigrants. Ann Behav Med 2011; 41:324-32.

69. Miller MJ, Yang M, Farrell JA, Lin L. Racial and cultural factors affecting the mental health of Asian Americans. Am J Orthopsychiatry 2011; 81:489-97.

70. Tovar A, Must A, Metayer N, Gute DM, Pirie A, Hyatt RR, et al. Immigrating to the US: what Brazilian, Latin American and Haitian women have to say about changes to their lifestyle that may be associated with obesity. J Immigr Minor Health 2013; 15:357-64

71. Kang S, Razzouk D, Mari J, Shirakawa I. The mental health of Korean immigrants in São Paulo, Brazil. Cad Saúde Pública 2009; 25:819-26.

72. Wen M, Maloney TN. Neighborhood socioeconomic status and BMI differences by immigrant and legal status: evidence from Utah. Econ Hum Biol 2013; 12:120-31.

73. Deeb-Sossa N, Olavarrieta CD, Juárez-Ramírez C, García SG, Villalobos A. Experiencias de mujeres mexicanas migrantes indocumentadas en California, Estados Unidos, en su acceso a los servicios de salud sexual y reproductiva: estudio de caso. Cad Saúde Pública 2013; 29:981-91.

74. Lahmam A, Baali A, Hilali MK, Cherkaoui M, Chapuis-Lucciani N, Boetsch G. Obesity, overweight and body-weight perception in a High Atlas Moroccan population. Obes Rev 2008; 9:93-9.
75. Gadd M, Sundquist J, Johansson S-E, Wendell P. Do immigrants have an increased prevalence of unhealthy behaviours and risk factors for coronary heart disease? Eur J Cardiovasc Prev Rehabil 2005; 12:535-41.

76. Molloy BL, Herzberger SD. Body image and selfesteem: a comparison of African-American and Caucasian women. Sex Roles 1998; 38:631-43.

77. Rosenmöller DL, Gasevic D, Seidell J, Lear SA. Determinants of changes in dietary patterns among Chinese immigrants: a cross-sectional analysis. Int J Behav Nutr Phys Act 2011; 8:42.

78. Kaushal N. Adversities of acculturation? Prevalence of obesity among immigrants. Health Econ 2009; 18:291-303.

79. Antecol H, Bedard K. Unhealthy assimilation: why do immigrants converge to American health status levels? Demography 2006; 43:337-60.

80. Novotny R, Williams AE, Vinoya AC, Oshiro CE, Vogt TM. US acculturation, food intake, and obesity among Asian-Pacific hotel workers. J Am Diet Assoc 2009; 109:1712-8.

81. Sanchez-Vaznaugh EV, Kawachi I, Subramanian SV, Sánchez BN, Acevedo-Garcia D. Do socioeconomic gradients in body mass index vary by race/ ethnicity, gender, and birthplace? Am J Epidemiol 2009; 169:1102-12.

82. Dey AN, Lucas JW. Physical and mental health characteristics of U.S.- and foreign-born adults: United States, 1998-2003. Adv Data 2006; (369): $1-19$.

83. Kaplan MS, Huguet N, Newsom JT, McFarland BH. The association between length of residence and obesity among Hispanic immigrants. Am J Prev Med 2004; 27:323-6.

84. Ulmann S, Goldman N, Pebley A. Contextual factors and weight change over time: a comparison between U.S. Hispanics and other population subgroups. Soc Sci Med 2013; 90:40-8.

85. Riosmena F, Wong R, Palloni A. Migration selection, protection, and acculturation in health: a binational perspective on older adults. Demography 2013; 50:1039-64.

86. Parikh N, Fahs M, Shelley D, Yerneni R. Health behaviors of older Chinese adults living in New York City. J Community Health 2009; 34:6-15.

87. Wang S, Quan J, Kanaya AM, Fernandez A. Asian Americans and obesity in California: a protective effect of biculturalism. J Immigr Minor Health 2011; 13:276-83.

Submitted on 15/Dec/2013

Final version resubmitted on 25/Sep/2014

Approved on 31/Oct/2014 